Steve Fuller*

\title{
Symmetry as a Guide to Post-truth Times: A Response to Lynch
}

\author{
https://doi.org/10.1515/auk-2021-0023
}

\begin{abstract}
William Lynch has provided an informed and probing critique of my embrace of the post-truth condition, which he understands correctly as an extension of the normative project of social epistemology. This article roughly tracks the order of Lynch's paper, beginning with the vexed role of the 'normative' in Science and Technology Studies, which originally triggered my version of social epistemology 35 years ago and has been guided by the field's 'symmetry principle'. Here the pejorative use of 'populism' to mean democracy is highlighted as a failure of symmetry. Finally, after rejecting Lynch's appeal to a hybrid Marxian-Darwinism, Carl Schmitt and Thomas Hobbes are contrasted en route to what I have called 'quantum epistemology'.
\end{abstract}

Keywords: symmetry principle, Science and Technology Studies, post-truth, Orwell, Carl Schmitt, Hobbes, populism, democracy, quantum epistemology

I must thank William Lynch for his very probing critique of my embrace of the posttruth condition, which he understands correctly as an extension-unwelcomed, in his eyes-of the normative project of social epistemology, in which he has been a fellow traveler almost from its inception (Fuller 1988). Indeed, I dedicated the first edition of Fuller and Collier (2004) to Lynch, while he was still a student at Virginia Tech. In what follows, I shall roughly track the order of Lynch's paper, beginning with the vexed role of the 'normative' in Science and Technology Studies (STS), which originally triggered my version of social epistemology 35 years ago. Lynch is right to zero in on the 'symmetry principle', whose status as properly 'normative' - as opposed to merely 'methodological' - has always been ambiguous. I next move to a more general consideration of the epistemic standing of 'democracy', which has been at the core of my sympathetic portrayal of post-truth. Here I focus on the pejorative use of 'populism' among contemporary epistemologists. Finally, I shall treat, in a more metaphysically

*Corresponding author: Steve Fuller, Department of Sociology, University of Warwick, Coventry, UK, E-mail: s.w.fuller@warwick.ac.uk

๖ Open Access. ๑ 2021 Steve Fuller, published by De Gruyter. $($ (c) BY This work is licensed under the Creative Commons Attribution 4.0 International License. 
expansive but critical way, Lynch's prospectus for a normative social epistemology that finds its footing in a mix of Marx and Darwin. Here I contrast Carl Schmitt and Thomas Hobbes, to the latter's benefit en route to what I have called 'quantum epistemology'.

\section{STS and the Normative Horizons of the Symmetry Principle}

The symmetry principle is arguably the most distinctive intellectual contribution of STS. It basically involves representing all agents from their standpoint and then turning the clash of perspectives into a research problem. It's not exactly 'neutrality' as normally understood, since that typically presumes the existence of a space, such as a courtroom, where one can adjudicate any dispute by following some established procedures. Rather, the sort of neutrality that is required for symmetry is one that STS inquirers are supposed to introduce, thereby proving their 'added value' to the proceedings. Long before the symmetry principle became familiar to sociologists, it had attracted philosophical attention-and mostly criticism (e.g. Brown 1984). After all, it seemed to license a second-order version of Socratic inquiry. Whereas Socrates interrogated interlocutors by first adopting and then reversing their perspectives, STS researchers would perform this 'bait and switch' on the entire dialectical situation, which may include more than two parties.

The symmetry principle was formally introduced by Bloor (1976). He was strongly influenced by the later Wittgenstein's remarks on rule-following, which in turn had been presented as a reflection on early twentieth century debates on the foundations of mathematics. This bit of history explains the principle's original intellectual ambition, which to their credit and in their own way, Bruno Latour and Steve Woolgar later realized much more clearly than Bloor and his colleagues at the Edinburgh Science Studies Unit (Latour and Woolgar 1979). Symmetry was meant to be a kind of 'reflexive relativism', which explains Latour (1988), one of the lightning rods of the 'Science Wars' of the 1990s. Latour correctly understood Einstein's revolution in physics as the relativization of relativism, yet without reverting to an absolute point of view, effectively saving the appearances of Newton's God without the need to postulate him. For Latour, this relativistic simulation of the absolute point of view amounts to a universal translatability principle for multiple moving frames of reference. It is also how I conceive of STS-style 'symmetry'. However, as a result of the bruising that STS took during the Science Wars, Latour and most others in the field retreated from this bold position, the legacy of which is the ambivalence towards symmetry that we see 
today. These are highlighted by Lynch in his opening remarks. In contrast, I have kept the faith.

Recall that 'relativism' as both an epistemic and ethical doctrine was the product of a naturalistic approach to anthropology associated with the first chair in the subject at the London School of Economics, Westermarck (1906; 1932), whose most famous student was Bronislaw Malinowski. Westermarck's view of culture as a population's long-term adaptive response to its environment provides the missing link between older 'blood and soil' views of culture (Kultur, related etymologically to 'agriculture') and latter-day evolutionary views associated with Spencer and Darwin. A distinctive feature of Westermarck's approach that influenced twentieth century positivist discussions of ethics was the role that he assigned to emotions in defining a population's psychic boundary, effectively placing limits on what they take to be reasonable. Here Westermarck wanted to find an anthropological basis for what Freud had called 'taboos' in family relationships. The political psychologist Philip Tetlock (2003) has taken the matter further by empirically probing the limits of 'taboo cognitions', which I see the post-truth condition as trying to transcend (Fuller 2018, ch. 7; 2020, ch. 1). I have characterized this taboo-busting tendency as 'changing the rules of the game', which in this context means altering the boundaries of what is reasonable and unreasonable to believe and do. In terms of Latour's Einsteinian inspiration, it is about changing the frame of reference.

Westermarck and his successors imagined a static geocentric world, in terms of which collective psychic boundaries emerge through regular interaction in a common space over a long time. This corresponds to the epistemological horizon of 'relativism' as philosophers normally understand it. It is quite different in spirit from the reflexive relativism of STS that flies under the banner of 'symmetry' - at least in its original bold formulation. That presupposed a much more dynamic universe, where the goal was to find a point of view capable of capturing all possible changes in frame of reference between all moving objects. I have referred to this alternative epistemic vision as constructivism, in deference to the antirealist spirit of Wittgenstein's philosophy of mathematics, whose full metaphysical potential I discovered as a student at Cambridge, largely after reading Dummett (1977). One of my first publications dealt with how I understood the issue at the time (Fuller 1983).

I originally drew the relativist-constructivist distinction in the context of Thomas Kuhn's (deleterious) influence on the development of STS, as his conception of 'paradigms' pushed the field down the path of relativism (Fuller 2000, ch. 7). Thus, STS tends to talk about scientific inquiry as constituting Westermarck-style 'epistemic cultures' and 'epistemic communities', each with its own hermetically sealed worldview and typically focused on regulating 
its borders (aka 'boundary maintenance'). This has led in recent years to two seemingly opposed lines of research that nevertheless share this common relativist horizon: on the one hand, the demarcation of expertise, which clearly aligns with today's establishment politics and is very much anti-post-truth (e.g. Collins and Evans 2007); on the other hand, the demarcation of counter-expertise, as introduced by Wynne (1982) but nowadays is associated with 'epistemic injustice', which aims to give voice to the local ('indigenous') knowledges that tend to be neglected or distorted by establishment forms of knowledge (e.g. Kidd, Medina, and Pohlhaus 2017).

My own view, as Lynch rightly realizes, might be called anti-expertise, reflecting that people are members of multiple groups at once and hence have multiple identities available to them. Thus, it becomes hard to establish their epistemic jurisdiction, especially if knowledge continues to be thought about in Westermarck-style, space-like, proprietary terms (à la 'domains of knowledge'). Even if one is both a citizen and, say, a religious believer, it doesn't follow that one prioritizes the epistemic horizons associated with these identities in the same way as the state. In a sense, I'm simply restating postmodernism as it was articulated as a theoretical proposition in the 1980 s and ' 90 s. However, the difference-in the wake of the internet and especially social media, both of which emerged later-is that everyone now can enact postmodernism in their everyday life. The designs that Facebook's Mark Zuckerberg has for launching the 'Metaverse' might take it all to another level.

I find it curious that people like Lynch have been blindsided by this development. They underestimate the extent to which movements of academic origin-not least postmodernism-both reflect their times and, by virtue of the teaching function of academics, seed the next generation of people capable of turning their interpretations into the text of reality. But seen from the long arc of history, it simply amounts to new technology enabling the extension of democracy, as newly educated people struggle to express their newly learned understandings of the world. 'Populism' is just a swear word in this context, but its revival as an epithet speaks to what Quine (1953) called 'referential opacity', which gets at the heart of the post-truth condition. Let me explain.

'Referential opacity' is the idea that the same reality can be accessed in mutually exclusive ways. It is based on Gottlob Frege's seminal insight - understood as a point of logic - that the history of science has often made progress by demonstrating that alternative bodies of evidence (and the meanings attached to them) are about the same thing, which science expresses in an 'extensional' language that preserves whatever truth is contained in these alternative approaches. Frege's textbook example was the discovery that both the 'Morning Star' and the 'Evening Star' refer to the planet Venus. This vision of inquiry, which somewhat resembles 
the fable of the blind men and the elephant, was shared by various nineteenth and twentieth century 'convergentist' philosophers, including William Whewell, Charles Sanders Peirce and Karl Popper. In their hands, it became a distinctive 'scientific' form of progress, separate from the more general doctrines of social progress that had been promoted in the eighteenth and early nineteenth centuries. However, this ultimate-perhaps even absolute-sense of 'truth' that science seeks is located in the indefinite future. In the meanwhile, 'truth' functions as a Kantian regulative ideal of reason, only now understood at a collective level. In the first half of the twentieth century, many linguistic reformers - not least the logical positivists - tried to design an ideal universal language that would be a suitable platform for resolving the referential opacity that was becoming evident in real time. Multiple cross-cutting ('orthogonal') patterns of inquiry were being conducted in an increasing number of natural languages (Gordin 2015, chs. 5-6). The term 'metalanguage' is the semantic residue of that original dream of translative resolution.

However, in the second half of the twentieth century, with the consolidation of American English as the lingua franca of science, analytic philosophers, starting with Quine and in the name of 'naturalism', installed the conceit of biasing this ideal towards the science $d u$ jour. In Quine's case it was behaviorism, but that was quietly dropped by his followers, especially after Chomsky's revolution in linguistics. The conceit was made explicit and developed most brilliantly by Hilary Putnam and Saul Kripke in the 1970s as the 'causal theory of reference'. Their followers generalized it as the ideology known as 'scientific realism', which still has admirers today (Leplin 1984). The conceit is that whatever happens to be the science $d u$ jour provides the metalanguage for resolving the multiple incommensurable perspectives on a common reality. Put bluntly, the scientific establishment is meant to determine the epistemic status quo, very much like the Pope who blessed the King in the Middle Ages (in exchange for support for the clerical estates), who are taken together as God's emissaries on Earth (Kantorowicz 1957). A version of this vision worked when Putnam and Kripke wrote-at the height of the Cold War-because at that point two-thirds of scientific research funding came from the state. Indeed, the royal-papal complex had morphed into the military-industrial complex, with 'Science' (i.e., with a capital 'S') functioning as the Holy Spirit that passes between the two.

The post-truth condition rejects this epistemic privileging of current science. After all, it amounts to making the nature of reality turn on the ever-changing moods of the scientific establishment-to the exclusion of non-establishment perspectives. In effect, one is being asked to treat the clever Venn diagrams and network graphs that scientometricians use to map the dynamics of organized inquiry as if they constituted epistemology, which is just as perspicuous as treating 
Ptolemaic astronomy as cosmology. Moreover, this homage to Ptolemy carries on, even though the excluded perspectives are better educated than ever, not least in the science from which they are formally excluded by virtue of, say, lacking an appropriate academic appointment. Moreover, taking the long view, if we consider the quite active transit between establishment and non-establishment views in the history of science, the hopelessly misnamed 'scientific realism' associated with the causal theory of reference starts to look like the product of a version of scientific fundamentalism. However, the 'fundament' here is not the Protestantstyle 'foundations' of modern epistemology, which is about clearing the mind of superfluous conceptions, but rather the Aristotle-inflected Catholic-style that is closer to terra firma, including its materialistic implications.

In short, what is called 'scientific realism' is little more than Westermarck's relativism projected on a planetary scale. In contrast, the post-truth condition treats referential opacity in a reflexively relativist fashion. In practice, this means that all perspectives are in principle equal: Any language could serve as the metalanguage, given the opportunity. It just depends on who controls the 'rules of the game', which is to say, the frame of reference. That is 'symmetry' in the sense that Latour originally introduced and from which he then retreated. It is ultimately supported by a counterfactually informed understanding of the history of science which recognizes that previously defeated, diminished and suppressed standpoints may rise again under the right conditions. (The trick is figuring out those conditions.) I have written of this as the 'pride of losers', which supports a 'Tory' (as opposed to 'Whig') historiography of science (Fuller 2003, ch. 9). For example, while Lynch correctly acknowledges that Pierre Duhem aspired-but failed-to leverage the history of science in just this way, nevertheless his contemporary Ernst Mach succeeded. Unfortunately, Mach himself died before his success was fully realized - but it happened nonetheless. His Science of Mechanics, which basically retells Newton's legacy from a self-styled 'critical-historical' standpoint, inspired both Einstein and Heisenberg in their quest to overturn the Newtonian orthodoxy in physics, despite Mach's vilification by the field's doyen at the time, Max Planck (Fuller 2000, ch. 2). And lest we forget, the logical positivist movement, which launched modern analytic philosophy, began as a circle in Vienna dedicated to Mach.

\section{What's in a Name: 'Democracy' or 'Populism'?}

I recently heard a talk by a rising star in the history and philosophy of logic, Catarina Dutilh Novaes, a research chair at the Free University of Amsterdam, who currently runs a European Research Council 'consolidator' project on the 
social epistemology of argumentation. She is clearly someone who has thought deeply about matters of concern here and is very admirable in her efforts to bring them into the public debate (e.g. Novaes 2017). I mention Novaes because her intuitions are quite like Lynch's, even though they come from a different intellectual space. They both believe that there are rules to argumentation, and if people don't follow them, then they're not worth speaking to. And at that point, one must start to consider non- or anti-discursive responses that exist along a spectrum that includes blocking, censoring, rehabilitating, and perhaps even incarcerating. It follows that John Stuart Mill-at least as philosophers tend to caricature him - would be too permissive for today's world, given the potential of social media to inhibit the development of a public sphere of rational discourse.

I clearly disagree with this entire line of thought, which is nevertheless of a piece with left-leaning US intellectuals who have wanted to, say, dissolve the Electoral College or pack the Supreme Court, simply based on politically disadvantageous outcomes they've suffered in the recent past and would wish to prevent in the future. However, my objection does not come from any sort of 'traditionalism'. On the contrary, if you're interested in radical change, then the case at hand must genuinely test the point you're trying to make, which means providing an opening for change that all-not only your side-can see for what it is. That's the principle behind what Bacon and Popper called a 'crucial experiment'. Otherwise, you run the risk of simply indulging in confirmation bias, whereby you start by assuming the truth of your position and then treating whatever doesn't validate it as problematic.

Moreover, when left-leaning people operate this way, they speak as the 'establishment' insofar as they presume that their grasp over what, say, the US Constitution means today is more secure than that of their opponents. Yet, these 'right-minded' leftists appear to be of two minds about whether today's 'populists' are too susceptible to what others say or not susceptible enough: Do populists need to close or open their minds more? If the answer is that they need to both 'close' and 'open' their minds, but in the 'right' ways, then I fear that these leftists have succumbed to a Ptolemaic brand of democracy. It doesn't help that this leftleaning establishment also tends to cherry pick past events to match the current case, resulting in a jimmy-rigged version of induction that is then presented as 'systemic' thinking. To be sure, 'anti-establishment' figures operate in a similar fashion, but then the establishment calls them 'conspiracy theorists'. Welcome to the world of STS symmetry!

What I have just described is the intellectual core of the post-truth condition-and it returns us to referential opacity. Imagine a world in which there were a democracy of frames of reference, whereby any of them could serve as the dominant one from which to observe the others-i.e., where multiple languages 
compete to be the metalanguage. But the proviso is that any such privileged frame of reference or metalanguage will at some point need to prove itself against competitors or simply return to its previous first-order status. That's how to translate Einstein's cosmic relativity into the 'natural attitude' of lived experience: The present should be seen as the reduction of possible pasts, only very few of which has been realized in the agent. But together they constitute a potential that contains different future trajectories that the agent might then realize. Implied here is an equation: agent $=$ power $=$ moment. This is how the Minkowski light cones in relativity theory came to animate the 'vortical' mentality of the Modernist movement in the 1920s.

I don't wish to go down the path of Pound, Eliot and Wyndham Lewis here. Nevertheless, what remains curious in this context is their 'Modernist' politics. Their 'radicalism' careened along the political spectrum of their times, typically settling somewhere 'right' of center. I would say that they could have benefitted from STS' symmetry principle to temper these violent left-to-right swings. At a more down to Earth level, Weinstein (2017), CEO of Thiel Capital and promoter of gauge theory in physics (aka hyper-relativity) as the new basis for economics, has spontaneously reinvented referential opacity as the 'Russell Conjugation', after Bertrand Russell, who in a 1948 BBC interview said something like this: 'I'm firm; you're obstinate; he's pigheaded'. Russell's point was that they are all talking about the same thing but their distance from the object influences both how they talk about it and how they regard others who talk about it.

In that spirit, consider the following exercise in symmetry: a translation manual for the post-truth condition, if you will. It is constructed in terms of 'My $\mathrm{X}$ is your Y', where $\mathrm{X}$ and $\mathrm{Y}$ are the same thing (aka 'extensionally equivalent') but described with opposed normative inflections.

\begin{tabular}{ll}
\hline My X... & $\ldots$ is your $\mathbf{Y}$ \\
\hline Democracy & Populism \\
Deliberation & Obfuscation \\
Rationality & Rules of the game \\
Systemic thinking & Conspiracy theory \\
Expert consensus & Groupthink \\
Critical inquiry & Trolling (or sealioning) \\
Accreditation & Academic rentiership \\
Enduring reality & Enforced ideology \\
Common sense & Filter bubble \\
\hline
\end{tabular}

A few explanatory points are required. Since I realize that 'deliberative democracy' continues to have fans, I strongly recommend as an antidote the 
political theorist Benjamin Barber's dialogue on the limits of deliberation as democratic expression (Barber 1988, ch. 5). Also, 'academic rentiership' refers to a range of academic practices that arrest the flow of knowledge, ranging from the need to secure at least one academic degree to be treated with respect in society to the need to avoid charges of plagiarism by crediting others for one's own efforts (Fuller 2019). Finally, I must thank Novaes for her injection of 'sealioning' into philosophical discourse to provide a refined understanding of trolling that corresponds more closely to what made Socrates the 'enemy of the people' that he turned out to be! But of greater significance is her parsing of the history of logic as a dispute between those who have seen it as being about 'discovery' versus 'dialogue' (Novaes 2017). The distinction is provocative because Novaes exploits the connotations of the opposition. She clearly wants us to think that 'discovery' is individualist (and destructively novelty-oriented) and 'dialogue' is collectivist (and more inclusive and encompassing) - and that we should 'return' to the more dialogical conception of logic.

However, in drawing this artificial distinction between discovery and dialogue, Novaes underestimates the emancipatory potential contained in the history of logic. Once Protagoras taught the Greeks the grammar of their own language, logic has been always dialogical-but it's been about getting ahead of the 'conversation', as Richard Rorty might say: If I want to win an argument, what should my interlocutors think the argument is about? Put more prosaically, the Sophists wanted to provide the means by which any citizen might set the metalanguage (aka 'rules of the game') in terms of which the distinction between true and false can be decided in the moment of dispute (kairos). What a radical idea! No wonder Plato wanted to stop it! Nevertheless, the idea resurfaced over the centuries, first with the Stoics and then the high medievals, to whom we owe the invention of various forms of modal logic, which continue to be fruitfully exploited to this day when making sense of physical reality. (Arthur Prior remains a good shepherd through all this.) From the standpoint of the post-truth condition, modal logic is about delimiting the sphere of possibilities with an eye to maneuvering in that space, or Spielraum. The spirit of the enterprise is epitomized in Bismarck's aphorism: 'Politics is the art of the possible' (Fuller 2018, ch. 6; 2020, ch. 3).

But of particular interest, considering Novaes' remonstrances against the 'discovery' orientation, is that the modern period streamlined the original thinking surrounding modal logic towards the so-called 'method of hypothesis', which Peirce later canonized as 'abduction'. Laudan (1981) alerted me to this trajectory, which helps to explain the Port Royal Logic, a seventeenth century tract by Calvinleaning followers of Descartes that aimed to render Galileo's heretical mode of reasoning logically respectable. It served to instantiate the distinction between the contexts of discovery and justification, which defined much of twentieth century 
philosophy of science. The distinction presumes the indeterminate identity of the fact, event, observation or finding (aka phainomenon) that is the bone of contention, to which multiple hypotheses are then provided to make sense of it. But how does one settle the matter? 'Discovery' in this context is about finding the hypothesis that outperforms all its rivals (aka 'inference to the best explanation'). It opens into a discussion of the 'criteria' (an old Stoic term) that should be used to rank the rivals. Here philosophers are effectively offering alternative blueprints for setting science's 'rules of the game'. This is clearly a second-order argument that is infused with competing forms of counterfactual reasoning, which are sometimes masked in its more quantified versions, such as Bayes Theorem. In any case, we're back to Protagoras - but there's nothing wrong with that. Indeed, if the history of logic were taught in the terms I've just sketched, everyone would be intellectually better prepared for the post-truth condition.

\section{The Matter of Social Constructivism and the Need to Go Quantum}

I have always been a 'social constructivist' but what I take that to mean has changed over time, as I've changed my understanding of the reality that the social agent (however defined) constructs. I began by thinking of reality as the literal product of the mind's transformation of whatever lies outside itself. In this context, 'matter' simply names whatever provides resistance to our efforts at such transformation, or 'realization' (e.g., Fuller 1988, ch. 10). Here I was influenced by the general perspective of the German philosophical tradition from Kant to Marx, notwithstanding differences in emphasis and formulation. It is profoundly antiAristotelian in its refusal to see matter as 'always already' inscribed with natures or essences, whose job it is for the mind to fathom. I found it telling that Marx first approached 'materialism' via atomism (in his PhD dissertation), which depicted Aristotle's observable 'common sense' world as simply transient combinations of more fundamental material principles. In short, Marx's envisaged matter as deep but not solid, which suits the metaphysics of capital-as in 'All that is solid melts into air'. But it immediately raised the question of who is shaping this indeterminate stuff, which opens into a discussion of the dominant social agents over time, aka 'classes' for Marx, but of course they have been identified otherwise.

While this remains perhaps the most recognizable form of social constructivism, my own view has drifted from it over the years. However, Lynch, who was a student of mine 30 years ago, still holds and has substantially developed it. Fuller (1993) was probably where our views were most closely aligned. And like other 
Marx-inspired thinkers of the recent past, Lynch has been drawn increasingly to a version of modern evolutionary theory-a kind of 'Neo-Darwinism Plus'. Levins and Lewontin (1985) established a paradigm for this line of thought on the biological side, and the more recent work of Bowles and Gintis (2011) stands out on the social science side. In between was Sober and Wilson (1998), who focused on the relative significance of 'selfishness' (aka capitalism) and 'altruism' (aka socialism) in evolution through a version of 'group selection', which leaves the open question of the level at which group membership matters.

What strikes me as most problematic in this general orientation is its underlying historical realism, a perennial source of dogmatism in Marxism that defeats the purpose of social constructivism, including the version supposedly espoused by the 'young', 'Hegelian' Marx, who inspired the reinvention of 'Western Marxism' in the 1960s. Such historical realism is what Popper (1957) first identified as 'historicism', in his idiosyncratic use of the term. It is what passes for 'materialism' in Marxist circles.

Nevertheless, historical realism has never really sat well with Marxists; hence the movement's passive-aggressive attitude to 'revisionism', a point that George Orwell probed to rich satirical effect in 1984. On the one hand, Marxism's legitimacy depends on regularly demonstrating its unerringly progressive trajectory, notwithstanding lived experience. In Orwell's novel, that is the job of the Ministry of Truth, which rewrites newspapers of the past to create to required historical backstory to whatever course of action on which the regime has embarked. On the other hand, those who challenge or even complain about this process are deemed 'revisionists' in the sense of enemies of the people. Such doublethink is possible because, as self-styled revolutionaries, Marxists aim to reboot the world, a concomitant of which is endless revisionism. It was symbolized by Year 1 of the French Revolutionary calendar-and repeated briefly during the Paris Commune in 1871 (Edelstein 2009).

After all, an implication of a radical change in worldview is that its effects propagate both forward and backward in time. We find new ancestors and project new descendants, the overall result of which is that some things that we thought were true turn out to be false, and vice versa-and some things that we thought were possible turn out to be impossible, and vice versa. When Popper described himself as a 'permanent revolutionary' vis-a-vis Kuhn's 'no revolution before its time' view of the history of science, he was appealing to this sensibility, which I have dubbed quantum epistemology (Fuller 2021). Although Popper credited Francis Bacon with the idea of a 'crucial experiment' as the vehicle capable of launching a scientific revolution, he might have been thinking of the doubleslit experiment in the quantum mechanics of his own day as demonstrating the full revolutionary potential of experimentation. It would certainly explain 
his lifelong fascination with getting straight the metaphysical implications of quantum mechanics.

However, this pro-revisionist, perhaps even (pace Popper) antirealist line of thought is ultimately unacceptable to Marxists at a metaphysical level because it renders the identity of the world-historic agents fundamentally indeterminate, which in turn threatens the straightforward progressivism on which the Marxist narrative ultimately depends. The more quantum approach, which embraces revisionism, identifies the agents with whomever seizes the moment, for as long as they can hold it. It follows that history is indeed written from the standpoint of the 'winners' - with the proviso that the game is always changing, such that today's winners may turn out to be tomorrow's losers-and vice versa. (See my earlier remarks about Mach.)

From this standpoint, narrative continuity is a fantasy (aka idealization) that motivates those wishing to seize the moment: You may think that your revolution or refutation will be the last, but it will not be-and you need the right metaphysics to cope with that level of uncertainty. Constitutional checks of the sort that require periodic elections regardless of track record are an institutional expression of this sensibility. It's a political invitation to counter-induction. If the ideological spread between the contesting parties is sufficiently wide, and the minds of the electorate are sufficiently open, such that the campaign matters to the outcome, the result is the sort of quantum moment that led to Brexit and Trump in 2016. Overnight a nation's direction of travel reverses - and in the US reversed again in 2020.

I believe that a healthy democracy tolerates-if not actively courts - such quantum moments. In that sense, American democracy is very healthy, even if the results on the ground don't look very pretty. But its full appreciation requires an open-minded sense of the agents of history - the boundaries of the collective, if you will. Transhistorical conceptions of such classic sociological categories as 'class', 'race' and 'gender' will not work. (The same applies to such classic biological categories as 'species', 'gene' and 'environment'.) This is not to say that such categories are useless, but they work only as rhetorical tokens to decide the exceptional case (kairos, as the Sophists said). Carl Schmitt and his followers across the ideological spectrum have understood this one point well: whoever/whatever decides the exceptional case (aka election, referendum, crucial experiment, etc.) determines the contours of reality: insiders/outsiders, normal/deviant, etc. But that's where their understanding ends. As we shall now see, Schmitt's view of the scope and significance of that exceptional state in a metaphysically restricted way, especially when compared with the main rival theorist of absolutism, Thomas Hobbes. 
Schmitt (1996) notoriously expressed the polity's moment of decision (kairos) in terms of 'friend or foe', which captured not only the approach of the Nazis, whom Schmitt supported, but also that of the French and Russian revolutionaries (Edelstein 2009). He presupposed a sense of 'negation' as a contrary relation. However, one need not see deciding the exception in such 'do or die' terms, whereby the excluded parties must be eliminated altogether. Instead, the policy might be modelled on contradiction, which would amount to simple 'rejection', resulting in ignoring or neglecting those who now lie outside of the newly redefined collective. In that case, the excluded parties must redefine themselves if they wish to be incorporated again. This is the way of 'ostracism', as practiced in classical Athens, Roman Catholic 'excommunication', which the Genevan Calvinists and the Massachusetts Puritans customized to their own purposes and which Rousseau later secularized to become criterial of modern republican citizenship. It is also apparent from post-Brexit Brussels. (I ignore here the 'witch trial' episodes of these societies, which are of course more Schmittian in spirit-but also tend to be seen retrospectively in a negative light.) A domesticated version of this approach appears in parliamentary politics, when the main losing party in an election serves as the government's official 'opposition' in the hope of getting back into government in the future. Schmitt found this 'softer', contradictory sense of negation unacceptably unstable.

My sense of the significance of the relationship between the 'contrary' and 'contradictory' senses of negation comes from Elster (1978), who had been inspired by Sartre (1960). The difference reveals the extent to which Schmitt was a prequantum thinker. Indeed, his political imagination was pre-Newtonian: It harked back to high medieval cosmology - part-Christian and part-Aristotelian - in which the term 'state' as status (as in status quo) was coined (Kantorowicz 1957). It was a world that presumed a divine emissary on Earth-King and/or Pope-who could restore the 'natural order' in the face of any violent swings. And by 'world' Schmitt clearly meant Earth (Schmitt 2003). The word 'revolution' originates from this worldview, one that is present as late as Shakespeare. Moreover, Schmitt adapted his medieval nostalgia to our more democratic times in the figure of the charismatic Führer who presented himself as a godlike creature who was nevertheless organically tied to his realm - a 'man of the people'. For Schmitt, this would constitute genuine progress in the history of democracy because it would not only realign democracy with the medieval worldview but also consolidate the spontaneously aggregate character of the demos into a coherent whole-Schmitt's sense of what healing the fallen state of humanity would look like as an historical achievement. Such was the telos of what he called 'political theology'.

Here it is worth noting Schmitt's dislike of Hobbes' approach to generating a being comparable to the divine emissary who enjoys absolute sovereignty: 
Leviathan. Notwithstanding Hobbes' much vaunted 'materialism', his social contract established only a mental connection with Leviathan. After all, it is simply a figment of the contracting parties' rational imaginations, which in turn explains the centrality of fear in Hobbesian moral psychology both before and after the social contract is agreed. Leviathan is supreme only because people have collectively come to accept its supremacy and have acted accordingly. Indeed, Hobbes was notorious in his day for the pride he took in having justified the absolute sovereign as no more than an 'artificial person'.

This shift from 'realism' to 'nominalism', if you will, in the personality of the sovereign also served to shift the definition of 'revolution' to imply that the sovereign rules only insofar as it enjoys the will of the people-because it lacks any other sort of basis for its existence. (There is no 'natural order' in the medieval sense for Hobbes.) This explains the subsequent development of social contract theory as the conceptual cornerstone of precisely the forms of 'liberal' democracy that Schmitt despised. These later theorists read Hobbes' Leviathan as a metaphor for anything - be it monarch, legislature, algorithm - that can do the requisite job of maintaining order, without the need to establish an 'organic' connection with the governed. The term of art favored in our liberalized Hobbesian world is 'rule of law', which US Founding Father John Adams embellished as 'an empire of laws, not men'.

While it might be a stretch to call Hobbes a 'quantum epistemologist', nevertheless he is closer than Schmitt to that perspective. Schmitt's sense of temporal infinity was that of eternity, which implies a transcendence of time altogether. The phrase 'unmoved mover' of medieval cosmology captured the place of God and his realm, Heaven, which in turn was imagined as an 'always already' perfect and unchanging place-a place that cancelled time once and for all. It is as if time itself were the expression of the Fall, and God and his emissaries are in a ceaseless struggle against temporality. This helps to explain Fascism's curious iconography, whereby an 'updated yet restored' version of a lost past is presented as counterpoint to the valorization of modernity for its own sake.

In contrast, Hobbes' sense of temporal infinity was that of perpetuity-a term that recurs in the US Constitution, Kant's 'cosmopolitan' vision of humanity, as well as in many legal instruments, including international treaties. In other words, whatever order there is in the world is created moment to moment indefinitely. The key phrase is moment to moment, which implies endless activity, effectively equating time itself with free will (or 'decision-making', as we say in modern secular times). There is no natural resting place. Order is simply the temporary arrest of motion; hence, it needs to be actively 'enforced' and 'maintained'. Recent STS-inspired work on 'infrastructure' is very much on point here. Today's innovation fetish reflects a neglect of the ingenuity-not to 
mention effort - that is involved in keeping already existing structures afloat (Vinsel and Russell 2020). It provides a broader perspective from which to think about Silicon Valley's anti-institutionalism (Morozov 2013).

The 'Newtonian Revolution' in cosmology was precisely about this shift in horizon, whereby motion rather than rest is physical reality's default setting. Unsurprisingly, the most exhaustive biography of Newton is entitled Never at Rest (Westfall 1981). Newton's is a world in which Hobbes could feel at home, but not Schmitt. Its narrative plot structure is driven by the endless struggle between inertial motion and gravitational attraction. The image of God implied in this vision has also understandably drawn latter-day Creationists and Intelligent Design Theorists to Newton as an exemplar of scientific inquiry: More than being a 'believer' simpliciter, Newton also seemed to believe in a deity who is just as active as his creatures in constructing the world, which in turn explained the ease with which the Newtonian God injected 'miraculous' events (aka free energy) to ensure that his clockwork universe didn't wind down. Of course, the Newtonian worldview was superseded in the twentieth century by the revolutions in relativity and quantum theory, but physical reality's default setting of bodies in motion rather than at rest remains. In that sense, physics remains in a 'Meta-Newtonian' condition. This explains why entropy, which predicts a long-term cosmic wind down, continues to monster theorizing in physics despite the paradigm shift from Newton to Einstein-as well as from the thermodynamics of energy to that of information.

In sum, an unfortunate casualty of the Science Wars of the 1990s was STS's ambition to become a full-blown metascience grounded in a universal symmetry principle. Latour had begun to show the way but then beat a hasty retreat and is nowadays celebrated for extolling the virtues of geocentrism (Latour 2018). In contrast, Lynch's retreat from universal symmetry has been intellectually more interesting and challenging than Latour's. It highlights deep issues about how we conceptualize both logical space and physical reality. Together they keep open the question about what it means to be 'realistic', which is just as it should be in the post-truth condition-and true to the original spirit of STS.

\section{References}

Barber, B. 1988. The Conquest of Politics: Liberal Philosophy in Democratic Times. Princeton: Princeton University Press.

Bloor, D. 1976. Knowledge and Social Imagery. London: Routledge.

Bowles, S., and H. Gintis. 2011. A Cooperative Species: Human Reciprocity and its Evolution. Princeton: Princeton University Press.

Brown, J. R. eds. 1984. Scientific Rationality: The Sociological Turn. Dordrecht: Kluwer. 
Collins, H., and R. Evans. 2007. Rethinking Expertise. Chicago: University of Chicago Press. Dummett, M. 1977. Truth and Other Enigmas. Oxford: Blackwell.

Edelstein, D. 2009. The Terror of Natural Right: Republicanism, the Cult of Nature and the French Revolution. Chicago: University of Chicago Press.

Elster, J. 1978. Logic and Society: Contradictions and Possible Worlds. Chichester: John Wiley.

Fuller, S. 1983. “A French Science (With English Subtitles).” Philosophy and Literature 7:1-14.

Fuller, S. 1988. Social Epistemology. Bloomington: Indiana University Press.

Fuller, S. 1993. Philosophy of Science and its Discontents, 2nd ed. New York: Guilford Press (Orig. 1989).

Fuller, S. 2000. Thomas Kuhn: A Philosophical History for Our Times. Chicago: University of Chicago Press.

Fuller, S. 2003. Kuhn vs Popper: The Struggle for the Soul of Science. Cambridge: Icon.

Fuller, S. 2018. Post-truth: Knowledge as a Power Game. London: Anthem.

Fuller, S. 2019. “Against Academic Rentiership: A Radical Critique of the Knowledge Economy." Postdigital Science and Education 1: 335-56.

Fuller, S. 2020. A Player's Guide to the Post-Truth Condition. London: Anthem.

Fuller, S. 2021. "Permanent Revolution in Science: A Quantum Epistemology." Philosophy of the Social Sciences 51: 48-57.

Fuller, S., and J. Collier. 2004. Philosophy, Rhetoric and the End of Knowledge, 2nd ed. Hillsdale: Lawrence Erlbaum Associates (Orig. 1993 by Fuller).

Gordin, M. 2015. Scientific Babel. Chicago: University of Chicago Press.

Kantorowicz, E. 1957. The King's Two Bodies. Princeton: Princeton University Press.

Kidd, I., J. Medina, and G. Pohlhaus, eds. 2017. The Routledge Handbook of Epistemic Injustice. London: Routledge.

Latour, B. 1988. “A Relativist Account of Einstein's Relativity.” Social Studies of Science 18: 3-44.

Latour, B. 2018. Down to Earth: Politics in the New Climatic Regime. Cambridge: Polity.

Latour, B., and S. Woolgar. 1979. Laboratory Life: The Social Construction of Scientific Facts. London: Sage.

Laudan, L. 1981. Science and Hypothesis. Dordrecht: Kluwer.

Leplin, J. ed. 1984. Scientific Realism. Berkeley: University of California Press.

Levins, R., and R. Lewontin. 1985. The Dialectical Biologist. Cambridge: Harvard University Press.

Morozov, E. 2013. To Save Everything, Click Here. New York: PublicAffairs Books.

Novaes, C. D. 2017. "What Is Logic?" In Aeon (17 January) the Rise and Fall and Rise of Logic|Aeon Essays.

Popper, K. 1957. The Poverty of Historicism. New York: Harper \& Row.

Quine, W. V. O. 1953. From a Logical Point of View. Cambridge: Harvard University Press.

Sartre, J. P. 1960. Critique de la Raison Dialectique. Paris: Gallimard.

Schmitt, C. 1996. The Concept of the Political. Chicago: University of Chicago Press (Orig. 1932).

Schmitt, C. 2003. The Nomos of the Earth. New York: Telos Press (Orig. 1950).

Sober, E., and D. S. Wilson. 1998. Unto Others: The Evolution and Psychology of Unselfish Behavior. Cambridge: Harvard University Press.

Tetlock, P. 2003. "Thinking the Unthinkable: Sacred Values and Taboo Cognitions." Trends in Cognitive Sciences 7 (7): 320-4.

Vinsel, L., and A. Russell. 2020. The Innovation Delusion. New York: Crown. 
Weinstein, E. 2017. "Russell Conjugation.” (In Response to 'What Scientific Term or Concept Should Be More Widely Known?') Edge.org.

Westermarck, E. 1906. The Origin and Development of Moral Ideas. London: Routledge \& Kegan Paul.

Westermarck, E. 1932. Ethical Relativity. London: Routledge \& Kegan Paul.

Westfall, R. 1981. Never at Rest: A Biography of Isaac Newton. Cambridge: Cambridge University Press.

Wynne, B. 1982. Rationality and Ritual: Participation and Exclusion in Nuclear Decision-Making. London: British Society for the History of Science. 